\title{
附子の品質と毒性に関する史的考察
}

\author{
大井 逸輝＼cjkstart河㟝＼cjkstart亮一＼cjkstart田中健太郎 \\ 御影 雅幸 \\ 金沢大学大学院医薬保健学総合研究科薬学系資源生薬学研究室, 石川, $\overline{1} 920-1192$ 金沢市角間町
}

\section{Herbological Study on the Quality and Toxicity of Aconite Root}

\author{
Itsuki OI Ryoichi KAWASAKI Kentaro TANAKA \\ Masayuki MIKAGE
}

Herbal Medicine and Natural Resources, Division of Pharmaceutical Sciences, Graduate School of Medical Sciences, Kanazawa University, Kakuma-machi, Kanazawa, Ishikawa 920-1192, Japan

\begin{abstract}
The crude drug Aconite Root (bushi in Japanese) contains toxic compounds called bushi diester alkaloids (BDA), and the raw material with high BDA content has been considered suitable for processing into prepared bushi. Moreover, processing methods and an upper BDA content limit are prescribed in the 16th edition of Japanese Pharmacopoeia. In this study, we closely examined descriptions of high quality bushi in ancient herbal literature, and elucidated the relationship between bushi forms and BDA contents. The results showed that large-sized bushi with enlarged rootlets called "horns" (tsuno in Japanese) were considered higher quality, and the horns and the root tops (hozo in Japanese) were cut off when used as bushi. Meanwhile, chemical studies have shown that larger bushi contains less BDA, and the root tops and the horns contain more BDA than the root body. These results suggest that selecting larger roots and cutting off the more potent parts were processes for reducing BDA. Therefore we conclude that consistently less toxic bushi was considered a higher quality product in ancient times.

Key words : Aconite Root, bushi diester alkaloids, processing, toxicity, herbological study

要旨

漢方生薬「附子」は強毒性のブシジエステルアルカロイド（BDA）を含むが，生薬原料には BDA 含量の高いも のがよいと考えられてきた。一方，第十六改正日本薬局方では減毒処理方法および BDA 含量の上限值が規定され た。本研究では, 古文献の附子の良品に関する記載内容を検討し, 附子の形状とBDA 含量の関係について調査し た。その結果, 大型で角（細根基部肥大部）がある附子が尊ばれていたこと, また使用時は, 原材料（子根）から 細根基部肥大部 (節·角) および根頭部（臍）を切り取る修治が行われていたことが明らかとなった。大型の附子 は BDA 含量が低值に安定し，根頭部（臍）および細根基部肥大部（角）は子根本体に比べて BDA 含量が高いこと が明らかになったことから, 選品においても修治法においても BDA 含量を低くする目的があった可能性が示唆さ れた。したがって，古来の良質品附子は毒性が低くかつ安定したものであったと考証した。 キーワード：附子, ブシジエステルアルカロイド, 修治, 毒性, 本草考証
\end{abstract}

\section{緒言}

キンポウゲ科トリカブト属植物 Aconitum spp. の 地下部に由来する生薬には附子，烏頭，天雄，烏喙， 側子などの種類があり，『重広英公本草』1a) $(934-$ 965）でこれらは大きさや形状で名称が異なると述 ベられている。トリカブト属植物の多くがブシジエ ステルアルカロイド（BDA）と総称される強毒性 の化合物群を含んでいる。BDAにはアコニチン (aconitine), メサコニチン (mesaconitine), ヒパコ
ニチン (hypaconitine), ジェサコニチン (jesaconitine）があり，有毒である一方で鎮痛作用，心血 管系への作用，神経接合部や胃腸管平滑筋に対する 作用の他, 抗炎症作用などが報告されている2)。古 来, これらの生薬は様々な修治法により加工されて きたが，これには生薬中の BDA 含有量が関係して いると考えられる。

『第十六改正日本薬局方』では「ブシ」として Aconitum carmichaeli Debeaux およびA. japonicum Thun- 
表 1 中国本草書の附子重量に関する記載

\begin{tabular}{|c|c|c|c|}
\hline \multicolumn{2}{|r|}{ 年代 } & \multirow{2}{*}{$\begin{array}{l}\text { 書名 } \\
\text { 雷公炮多論 }{ }^{1 b)}\end{array}$} & \multirow{2}{*}{$\begin{array}{l}\text { 記載内容 } \\
\text { 若用附子須底平有九角如鉄色一個重二両気全 }\end{array}$} \\
\hline $\begin{array}{l}\text { 南朝· } \\
\text { 鉼鉒 }\end{array}$ & 420-479 & & \\
\hline 宋 & $\begin{array}{c}1116 \\
12 \text { 世紀初 }\end{array}$ & $\begin{array}{l}\text { 本草衍義1c) } \\
\text { 彰明附子記 }^{1 d)}\end{array}$ & $\begin{array}{l}\text { 須用附子仍取其端平而圓大及半両以上者其力全 } \\
\text { 土人有知薬者云小者固難用要之半両以上皆良 }\end{array}$ \\
\hline 元 & 1331 & 本草元命苞 ${ }^{1 \mathrm{~g})}$ & 端平而圓大及二禹堪用 \\
\hline \multirow{11}{*}{ 明 } & 1384 & 薬準 ${ }^{\text {lh) }}$ & 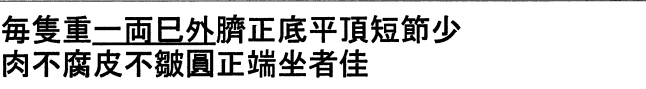 \\
\hline & 1551 & 薬性粗評吕) & 附子以底平八角一箇重二両者気全 \\
\hline & 1565 & 本草蒙筌 & 二両一枚者カ大 \\
\hline & 1578 & 本草發明1k) & 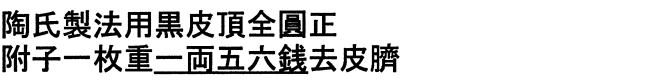 \\
\hline & 1595 & 薬性会元 ${ }^{11)}$ & 端平圓大二両以上其力全 \\
\hline & 1596 & 本草網目 ${ }^{1 \mathrm{~m})}$ & 二両者極難得土人云但得半両以上者皆良 \\
\hline & & 増補薬性雷公炮製1n) & 重二両即是気全 \\
\hline & 1602 & 李東垣薬性大全 ${ }^{10)}$ & 附子団圓平坐重二両巳上者佳 \\
\hline & 1612 & 本草原始 ${ }^{1 p)}$ & 一箇重二両者気全堪用 \\
\hline & 1622 & 雷公炮製薬性解 ${ }^{1 q)}$ & 択毎隻重二両者 \\
\hline & 1637 & 医宗必読1r) & 重二両以上矮而孔節稀者佳 \\
\hline \multirow{9}{*}{ 清 } & 1655 & 本草通玄 ${ }^{1 s)}$ & 附子以蹲坐正節角少重二両者佳 \\
\hline & 1663 & 本草崇原 ${ }^{1 t)}$ & 如用附子本身有二両余者方為有力 \\
\hline & 1681 & 本草詳節1u) & 須択頂圓正節角少色花白重二両者 \\
\hline & 1691 & 薬品弁義1v) & 一枚重両二三銭力足可用 \\
\hline & 1694 & 本草備用 ${ }^{1 e)}$ & 重二両以上者良或云二両者更勝然難得. \\
\hline & 1695 & 本経逢原 ${ }^{1 w)}$ & 古方以二両一枚者為力全 \\
\hline & 1758 & 医林纂要探源 ${ }^{1 x)}$ & 皮黒体圓繂平下尖八角重二両外者良 \\
\hline & 1773 & 本草求真 ${ }^{1 y)}$ & 皮黒体圓底平八角重三両者良 \\
\hline & 1917 & 増訂偽薬條弁 ${ }^{1 z)}$ & 重両許者気全最佳 \\
\hline
\end{tabular}

bergの二種が原植物として定められている。品質 に関しては，これまでブシ原料の BDA 総量を増や すことが育種目標の一つと考えられてきたが4)，第 16局では BDA 総量を $450(\mu \mathrm{g} / \mathrm{g})$ 以下と規定した。 このことはブシを安全に使用することを目的とした ものと考えられるが，近年，ブシのアルカロイド以 外の水溶性成分に体温上昇作用があることが報告さ れる5゙ど，BDAのみでの品質評価は困難であると 考えられる。一方，古来，附子類は大きさ，太さ， 長さなどの形状で評価されてきたことから，これら の形状が薬効や毒性の強弱に関連していることが予 想される。そこで本研究では, 本草書の附子の良品 に関する記載内容を検討し, さらに考証結果を化学 的に検証することを目的として，附子の形状と成分 の相関を調査し, 毒性の強弱を BDA を指標として 評価した。

\section{1. 附子の重量について（表 1，表 2 )}

『雷公炮采論』(b) $(420-479)$ に「一個重一両, 気全」とあり, 附子一個の重さ一両のものは薬気が 完全であり用いるべきであると記され，多くの本草 書にこの引用があらわれる。『本草衍義』(10)（1119） や『彰明附子記』1d) (12世紀初期) のように半両以 上という記載も見られるが，多くは「一両」と記載 されている。『本草備用』1e)（1694）では「重一両以 上者良, 或云二両者更勝, 然難得」と, より重いも のが良い附子であると記述していることから，古来， 中国では概ね一両以上の重さの附子が良品とされて いたことが窺える。日本の本草書でも一両以上, 十 多以上や十銭以上，また十六個ほどで一斤の重さに なるものが良品とされる記載が認められる。一両は 十多あるいは十銭，一斤は十六両であるので，日本 でも重量一両を境に附子の良否を判断していたこと が明らかになった。 
表 2 日本本草書の附子重量に関する記載

\begin{tabular}{|c|c|c|}
\hline 年代 & 書名 & 記載内容 \\
\hline 1681 & 本草弁義拿) & 重サ土多巳上アル皺ナククサリナキヨ用ヘシ \\
\hline 1689 & 炮多全書 ${ }^{1 \mathrm{~B})}$ & 重二両以上‥者佳 \\
\hline 1698 & 広益本草大成 ${ }^{1 C)}$ & 重サ土銭目以上ノ者ヨ上品トス \\
\hline 1709 & 大和本草 ${ }^{1 D)}$ & $\begin{array}{l}\text { 重サ土文目以上ナルヨ尤良トス十文目以上ハマレナリ } \\
\text { 五文目以上モ良ト本草ニイヘリ大ナルヨ良トス }\end{array}$ \\
\hline 1712 & 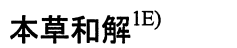 & 重サ土多巳上アル皺ナク朽ナキヨ用可シ \\
\hline 1723 & 本草製譜 ${ }^{\mathrm{F})}$ & $\begin{array}{l}\text { 重サ土銭且以上ノ者最為上然モ十銭以上ノ者至稀也 } \\
\text { 五銭目以上ノ者可用 }\end{array}$ \\
\hline 1728 & 薬籠本草 ${ }^{1 \mathrm{G})}$ & 三三銭ヨリ八九銭二至者Э最上ノ好附子卜為也 \\
\hline 1729 & 一本堂薬選 ${ }^{1 \mathrm{H})}$ & $\begin{array}{l}\text { 凡ソ附子ヨ撰ブニ大ナル者ヨ以佳卜為十六枚ヨ以二丘為者是也 } \\
\text { 又七八枚十枚ヨ而二丘ナル者有益良シ }\end{array}$ \\
\hline 1756 & 袖珍本草售 ${ }^{11)}$ & 二両以上矮ニシテ而孔節稀ナル者佳 \\
\hline 1778 & 千金方薬注 ${ }^{1 J)}$ & 一箇重サ土鉞ノ者ハ気全シコレラ佳トス \\
\hline 1780 & 六八本草 ${ }^{1 K)}$ & $\begin{array}{l}\text { 身矮ク乳稀ニシテ重サ二両五銭ノ者佳… } \\
\text { 重サー車五銭ハ㚃斤テ十フ掛ノ附子ナリ大抵十五六掛バ佳トス }\end{array}$ \\
\hline 1784 & 薬徴1L) & $\begin{array}{l}\text { 一両者難得但得半両以上者皆良 } \\
\text { 今漢客来粥者大及二両小不下半 }\end{array}$ \\
\hline 1803 & 本草綱目啓蒙 ${ }^{1 f)}$ & 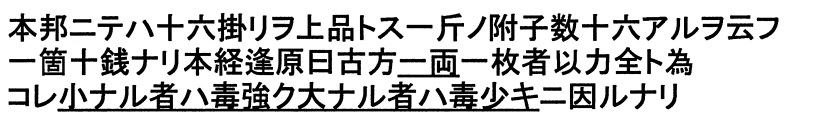 \\
\hline 1842 & 古方薬品考 ${ }^{1 \mathrm{M})}$ & 十六七枚或ハ二十三五枚ヨ以テニ丘二満ル者ヨ最上ト為ス \\
\hline
\end{tabular}

表 3 角, 節, 鼠乳に関する記載

\begin{tabular}{|c|c|c|c|}
\hline & 年代 & 書名 & 記載内容 \\
\hline $\begin{array}{l}\text { 南朝· } \\
\text { 劉宋 }\end{array}$ & $420-479$ & 雷公炮多論 & 若用附子須底平有九角如鉄色一個重一両気全 \\
\hline 梁 & $502-536$ & 神農本草経集注 $^{1 \mathrm{~N})}$ & 附子以八月上旬採八角者良 \\
\hline \multirow[b]{2}{*}{ 宋 } & 1062 & 図経本草 ${ }^{1 a)}$ & 附子以八苗者為上 \\
\hline & 12世紀初 & 彰明附子記 & $\begin{array}{l}\text { 附子之形以蹲坐正節角少為上有節気多鼠乳者次之形... } \\
\text { 又云附子八角者良 }\end{array}$ \\
\hline \multirow{3}{*}{ 明 } & 1384 & 薬準 & 頂短節少肉不腐皮不媰圓正端坐者佳 \\
\hline & 1551 & 薬性粗評 & 附子以底平八角一箇重一両者気全 \\
\hline & 1637 & 医宗必読 & 重一両以上矮而孔節稀者佳 \\
\hline \multirow{6}{*}{ 清 } & 1655 & 本草通玄 & 附子以蹲坐正節角少重一両物佳 \\
\hline & 1681 & 本草詳節 & 須択頂圓正節角少 \\
\hline & 1694 & 本草備要 & 皮黒体圓底平八苗重一両以上者良 \\
\hline & 1695 & 本経逢原 & 必正節角少頂細臍正者為上頂粗有節多鼠乳者次之 \\
\hline & 1757 & 本草従新 ${ }^{10)}$ & 皮黒体圓底平八苗頂大者良 \\
\hline & 1758 & 医林纂要探源 & 皮黒体圓臍平下尖八角重一両外者良 \\
\hline \multirow{4}{*}{ 江戸 } & 1685 & 図解本草 ${ }^{1 P)}$ & 附子ノ状チ八角ノ者Э以テ上ト為 \\
\hline & 1778 & 千金方薬注 & $\begin{array}{l}\text { 八魚ニシテ坐平ラカニー箇重サ十銭ノ者ハ } \\
\text { 気全シコレ 佳トス }\end{array}$ \\
\hline & 1780 & 六八本草 & $\begin{array}{l}\text { 身矮ク乳稀ニシテ重サー両五銭者佳… } \\
\text { 乳稀ナリハハ皮ニコフガアルモ/此ハ切テ捨ツル } \\
\text { ユヘニ乳多キ附子ハスタル所多シ }\end{array}$ \\
\hline & 1803 & 本草綱目啓蒙 & $\begin{array}{l}\text { 形大ナルヨ大附子或八八角附子ト云フ } \\
\text { 至テ大ナルモノニハ疙㾂(イボ)アリ故二八角附子卜云フ }\end{array}$ \\
\hline
\end{tabular}


度量衡に関して, 質量の基準は唐代以来，変化が 無く, 一両は中国度量衡史によると $37.3 \mathrm{~g}$ であり, 日本の十多は $37.5 \mathrm{~g}$ と定められている ${ }^{6)}$ 。両者の差 は一般商業用の棒はかりにはあらわれない程度であ るとされる。一般に薬物の度量衡には, 小称という 通常の両の三分の一に換算された単位が使われたこ とから，附子の良否基準とされた一両は $12.5 \mathrm{~g}$ 程度 である。生重量 $12.5 \mathrm{~g}$ の子根では小さすぎることか ら，この值は乾燥重量を示していると考えられる。

また『本草綱目啓蒙』1)（1803）には，「小ナル者 八毒強ク, 大ナル者八毒少キ」とあり, 大型の附子 は毒性が低いため良品であるという記載がある。こ れに関して, Kawasaki ら〕は子根重量の増加により BDA 含量のバラツキが低值に安定することを明ら かにしている。したがって，大型の附子が良品とさ れてきたことは, BDA 含量が少なく安定した毒性 の低いものが求められていたことを意味すると考察 できる。

\section{2. 附子の形状 (1 ) : 角, 節, 鼠乳について（表} 3 )

『神農本草経集注』1N（502-536）に「八角者良」 が初出以降，八角の附子が良品とされてきた。一方 で『彰明附子記』には，「附子之形以，蹲坐正，節 角少者, 為上。有節気多鼠乳者, 次之形」と記載が あり，角も節も少ないものが良く，鼠乳についても 望ましくないとされていた。

「角」が指す意味に関して，『本草綱目啓蒙』に は「形大ナルョ大附子或八八角附子卜云フ, 至テ大 ナルモノニ八疮㽽（イボ）アリ，故二八角附子卜云 フ」と記されており，八角附子は大型の附子であり， 「角」はつの（尖った部分，イボ）を指していたと 判断される。トリカブト属植物の子根は一般に成長 するにしたがって, 細根基部が肥大し, 膨らんだ部 分が増えていく。この細根基部の肥大部がイボや角 と呼ばれ，「八角」は子根に細根基部肥大部が多い 様を示していたと考えられる。さらに大型の附子を 八角附子とする記載は前節の重量の大きな子根を良 品とする考察と矛盾しない。したがって, 図 1 に示 すような形態が八角附子であると判断した。一方，

『彰明附子記』の記載では角が少ないものが良品で あるとしており, 八角を良品とする記載と逆の内容 が述べられている。しかし，『雷公炮多論』に「去 皮尖底薄切」という記載があり, 附子の修治として

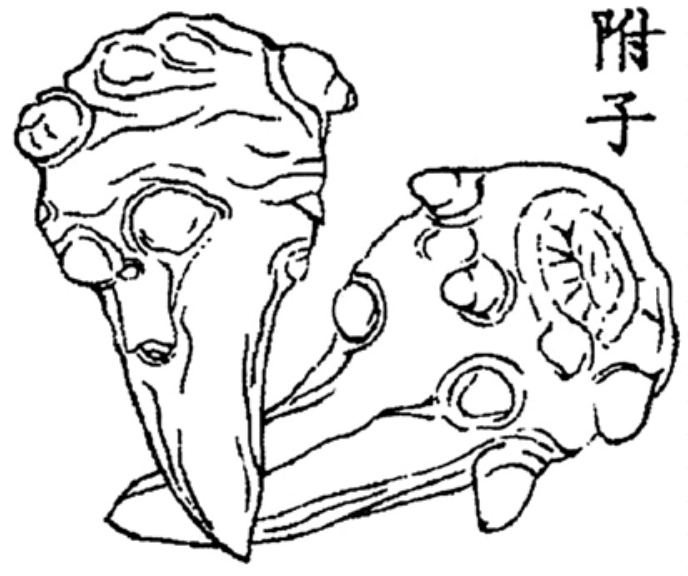

図 1 古方薬品考の付図

皮，尖，底を取り除くとある(表 4$)$ 。この記載の 「尖」は細根の基部肥大部すなわち角を指している ものと考えられる。また，皮を去るとする記載はそ の他多くの本草書に記されているが，皮を削り取る のと同時に角も取り除かれていたことが予想される。 「八角」は子根収穫時の良品であり,「角少者」は 加工後の形状を示していたとすれば辻褄が合う。

また「節」は区切り，ふし，さかい目の意である。 節が少ないことが望まれていることと，記載の多く は角と節を同列に扱うことから，角と同様に細根基 部の肥大部であると推測した。

「鼠乳」については『六八本草』K) (1723) に「乳 稀ナリトハ皮ニコブアルモノ此ハ切テ捨ツルユエ」 とあり, 乳（鼠乳）も細根基部の肥大部であると考 えられる。附子の細根基部肥大部は大小様々であり， 「鼠乳」はネズミの乳首のような形をした小型のも のを指すと判断できる。

以上, 細根基部の肥大がみられるような大型の附 子が古来良品とされており, 使用時には細根基部の 肥大部を取り除くべきであるとされてきたと考察し た。な扮「底」については後述する。

\section{3. 附子の形状 (2)：底, 坐, 䀮について}

前述の角, 節, 鼠乳の他に, 附子の形状を示す用 語に『雷公炮采論』の「底平」や『彰明附子記』の 「蹲坐」がある（表 5 )。蹲坐とは，「うずくまって 尻を地面につけて座る」との意味であるが, 収穫さ れた塊根に底が平らなものや蹲坐した形状のものは 見られない。しかし『本草原始』点) (1612) の付図 に示される附子は底が平らに描かれ, 蹲坐「地面に うずくまって坐る」という表現にあてはまる（図 2 )。ここでは底, 坐, 臍などの用語について検討 
表 4 修治における除去部位

\begin{tabular}{|c|c|c|c|}
\hline & 年代 & 書名 & 記載内容 \\
\hline $\begin{array}{l}\text { 南朝· } \\
\text { 劉宋 }\end{array}$ & $420-479$ & 雷公炮多論 & $\begin{array}{l}\text { 以刀刮去上孕子併去底尖 } \\
\text { 埋土取出暴乾用若陰製者生去皮尖底薄切 }\end{array}$ \\
\hline 唐 & 739 & 本草拾遺1a) & 附子酢浸削如小指内耳中去竩去皮 \\
\hline 宋 & 1062 & 図経本草 & 如方薬要用須炮令裂去皮臍 \\
\hline 蒙古 & 1248 & 湯液本草 ${ }^{10)}$ & 烏附天雄側子之属皆水浸炮裂去皮臍用之 \\
\hline 元 & 1295 & 本草歌括 ${ }^{1 R)}$ & 炮裂去皮臍尖 \\
\hline \multirow{11}{*}{ 明 } & 1384 & 薬準 & $\begin{array}{l}\text { 童便浸三日以甘草汁浸過湿紙包慢火中煨 } \\
\text { 令極熟去皮臍切五再炒内外俱黄用 }\end{array}$ \\
\hline & 15世紀末 & 神農本経会通 ${ }^{1 S)}$ & 凡使水浸文武火炮令裂表裏皆黄折去皮臍用 \\
\hline & 1551 & 薬性粗評 & 陰制者生尖底併皮薄切 \\
\hline & 1565 & 本草蒙筌 & 以刀去浄皮臍 \\
\hline & 1578 & 本草發明 & $\begin{array}{l}\text { 陶氏製法用黒皮頂全圓正 } \\
\text { 附子一枚重一両五六銭去皮臍 }\end{array}$ \\
\hline & 1596 & 本草綱目 & $\begin{array}{l}\text { 生用者須如陰制之法去皮臍入薬 } \\
\text { 熟用者以水浸過炮令折去皮臍... }\end{array}$ \\
\hline & 1600年頃 & 仁寿堂薬鏡 ${ }^{1 T)}$ & 童便浸三日去皮臍切作四塊 \\
\hline & 1602 & 本草真詮 ${ }^{1 U)}$ & 黒豆水浸五日去皮臍 \\
\hline & 1622 & 炮多大法 ${ }^{1 \mathrm{~V})}$ & 用刀刮上孕子併去底尖微細䢃破 \\
\hline & 1622 & 雷公炮製薬性解 & 去皮臍以薑汁塩水煮数沸 \\
\hline & 1637 & 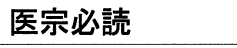 & 童便浸一日去皮切四片 \\
\hline \multirow{6}{*}{ 清 } & 1660 & 本草彙箋1W) & 附子入薬去皮臍 \\
\hline & 1663 & 本草崇原 & 製附子之法以刀削去皮臍剖作四塊 \\
\hline & 1681 & 本草詳節 & 凡使去皮尖併臍 \\
\hline & 1724 & 本草経解要 ${ }^{1 X)}$ & 便浸水煮去皮臍用 \\
\hline & 1757 & 本草従新 & 修治法‥附子泡浸剥去皮臍切作四塊 \\
\hline & 1852 & 仙製本草 ${ }^{1 Y)}$ & 宜泡皺折後去皮尖底用 \\
\hline \multirow{2}{*}{ 江戸 } & 1712 & 本草和解 & 熱灰入煨シテ皮臍ヨ去テ剉二用ユ \\
\hline & 1729 & 一本堂薬選 & 用ユル時皮ヨ去，頭尖孕子ᄏ削下シ… \\
\hline
\end{tabular}

表 5 底，坐，臍に関する記載

\begin{tabular}{|c|c|c|c|}
\hline & 年代 & 書名 & 記載内容 \\
\hline $\begin{array}{l}\text { 南朝· } \\
\text { 劉宋 }\end{array}$ & $420-479$ & 雷公炮多論 & 若用附子須底平有九角如鉄色一個重一両気全 \\
\hline \multirow{2}{*}{ 宋 } & 1116 & 本草衍義 & 須用附子仍取其端平而圓大半両以上者其力全 \\
\hline & 12世紀初 & 彰明附子記 & 附子之形以蹲坐正節角少為上 \\
\hline 元 & 1331 & 本草元命苞 & 端平而圓大及一両用堪 \\
\hline \multirow{4}{*}{ 明 } & 1384 & 薬準 & 臍正底平頂短節少肉不腐皮不媰圓正端坐者佳 \\
\hline & 1551 & 薬性粗評 & 附子以底平八角一箇重一両者気全 \\
\hline & 1565 & 本草蒙筌 & 皮黒体圓底平 \\
\hline & 1602 & 李東垣薬性大全 & 附子団圓平坐重一両巳上者佳 \\
\hline \multirow{8}{*}{ 清 } & 1655 & 本草通玄 & 附子以蹲坐正節角少重一両物佳 \\
\hline & 1681 & 本草詳節 & 須択頂圓正 \\
\hline & 1691 & 薬品弁義 & 取皮黒頂平臍正者佳 \\
\hline & 1695 & 本経逢原 & 必正節角少頂細臍正者為上 \\
\hline & 1757 & 本草従新 & 皮黒体圓底平八角頂大者良 \\
\hline & 1758 & 医林纂要探源 & 皮黒体圓臍平下尖八角重一両外者良 \\
\hline & 1790 & 本草輯要 ${ }^{1 Z)}$ & 皮黒体圓底平八角重－両以上者良 \\
\hline & 1917 & 増訂偽薬條弁 & 底平有角 \\
\hline 江戸 & 1709 & 大和本草 & 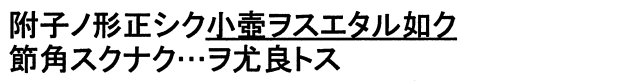 \\
\hline
\end{tabular}




\section{者角入用条中方古}
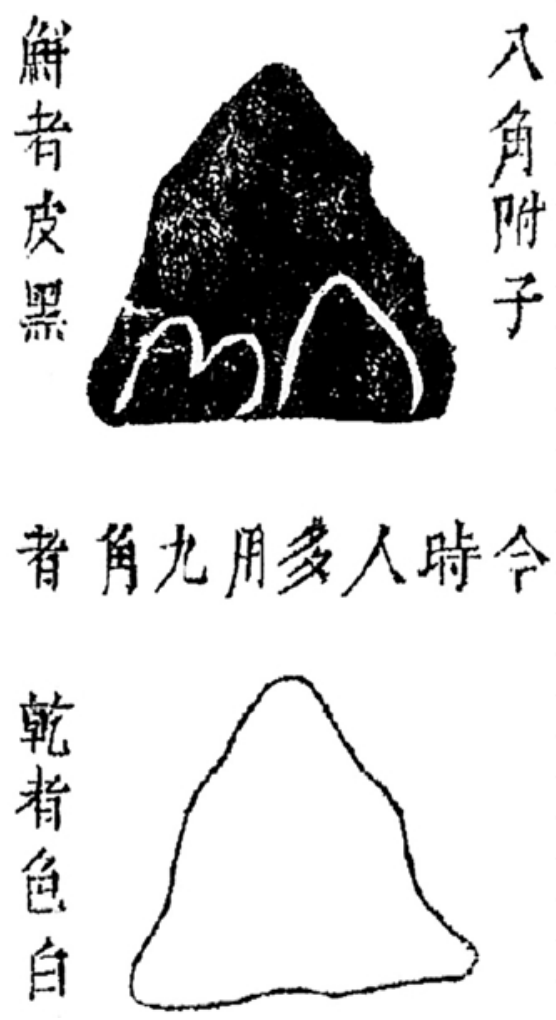

図 2 本草原始の付図

\section{した結果を述べる。}

『図経本草』』a) (1062) 以後，附子の「臍」を除 去するとした記載がみられるようになる（表4）。 臍はへその意であり，(1)子根のへそのような形態の 部位（越冬芽が乾燥により萎んで平らあるいは凹ん だ部分。根頭部）と，(2)子根と母根の結合部分のい ずれかを指すと推測された（図 3)。(1)の場合は図 3 の切断面 a , (2)の場合は切断面 b で切除すると考 えられるが，『医林纂要探源』1x)（1758）に「臍平， 下尖八角，重一両外者良」とあり，平らな面を作る には切断面 $\mathrm{b}$ で切除することになる。したがって臍 を去るとは根頭部の切除を意味すると判断した。根 頭部を除去し，さらに角を除去し，上下を逆にする と, 先述の「底が平ら」で「蹲坐」する附子となり, 本草原始の付図と合致する（図 4 ）。以上のことか ら,「底平」と「蹲坐」の記載も子根を加工した後 の形状を示し，すなわち根頭部を除去した附子が良 品とされていたと考察した。

\section{4. 化学的研究 : 子根部位による BDA 含量の相違} 本草考証により, 古来, 大型の附子が良品とされ

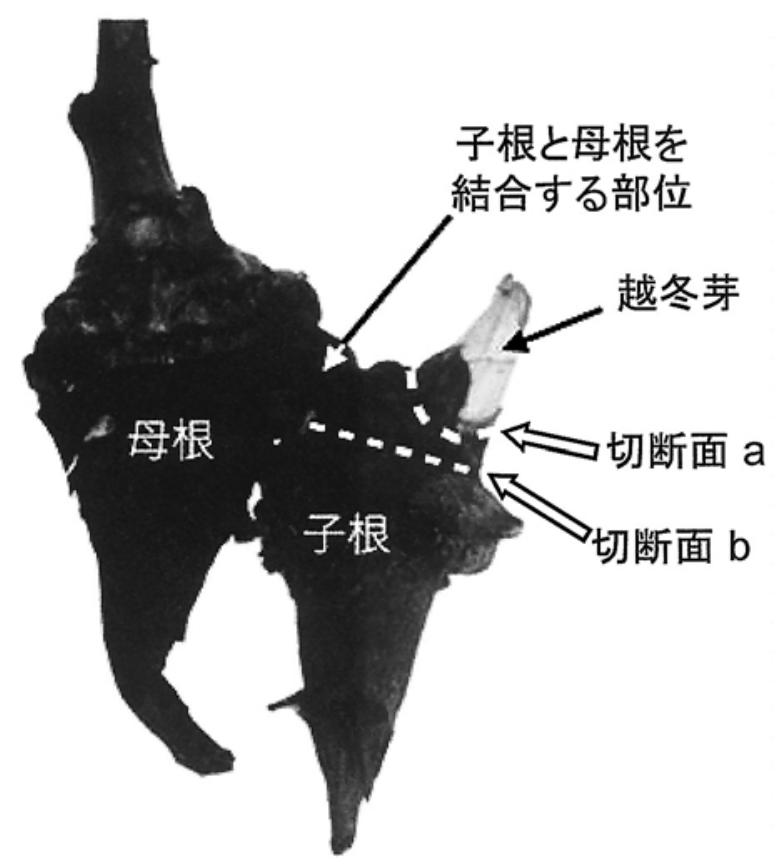

図 3 臍として切断する部位（生根）

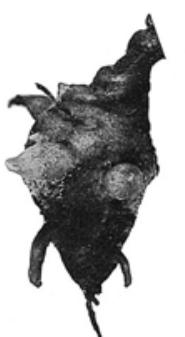

(1)

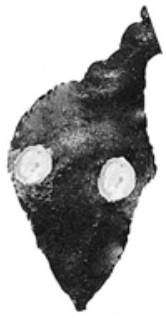

(2)

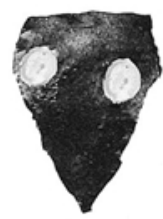

(3)

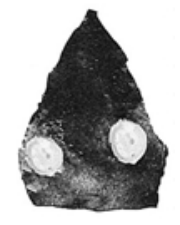

(4)
図 4 良質品附子の修治法（生の子根）

(1)：収穫した状態，(2)：細根基部の肥大部（角）を取 り除いた状態，(3)：越冬芽周辺部（根頭部・臍）を取 り去った状態，(4)：上下を逆さまにした状態（本草原 始の付図, 図 2 に似る)。

たのは低毒性であることに基づくと考察した。加え て, 良質品附子を製造するために, 細根基部の肥大 部（角）や根頭部（臍）を切除する修治が行われて いたことを明らかにした。そこで細根基部の肥大部 や根頭部を子根から切り離す意義を化学的な観点か ら評価するため, 子根各部位の BDA 含量を測定し た。

\section{1 ）実験材料}

生薬材料：大川烏（日野製薬株式会社，1995年） 7 個，川烏（株式会社栃本天海堂，2004年） 4 個。 これらは川烏（烏頭）の名がついているが，形態よ り子根由来であると判断された。

試薬：ブシジエステルアルカロイド標準品〔和光 純薬工業株式会社：Lot. No. WKF6774，アコニチン 


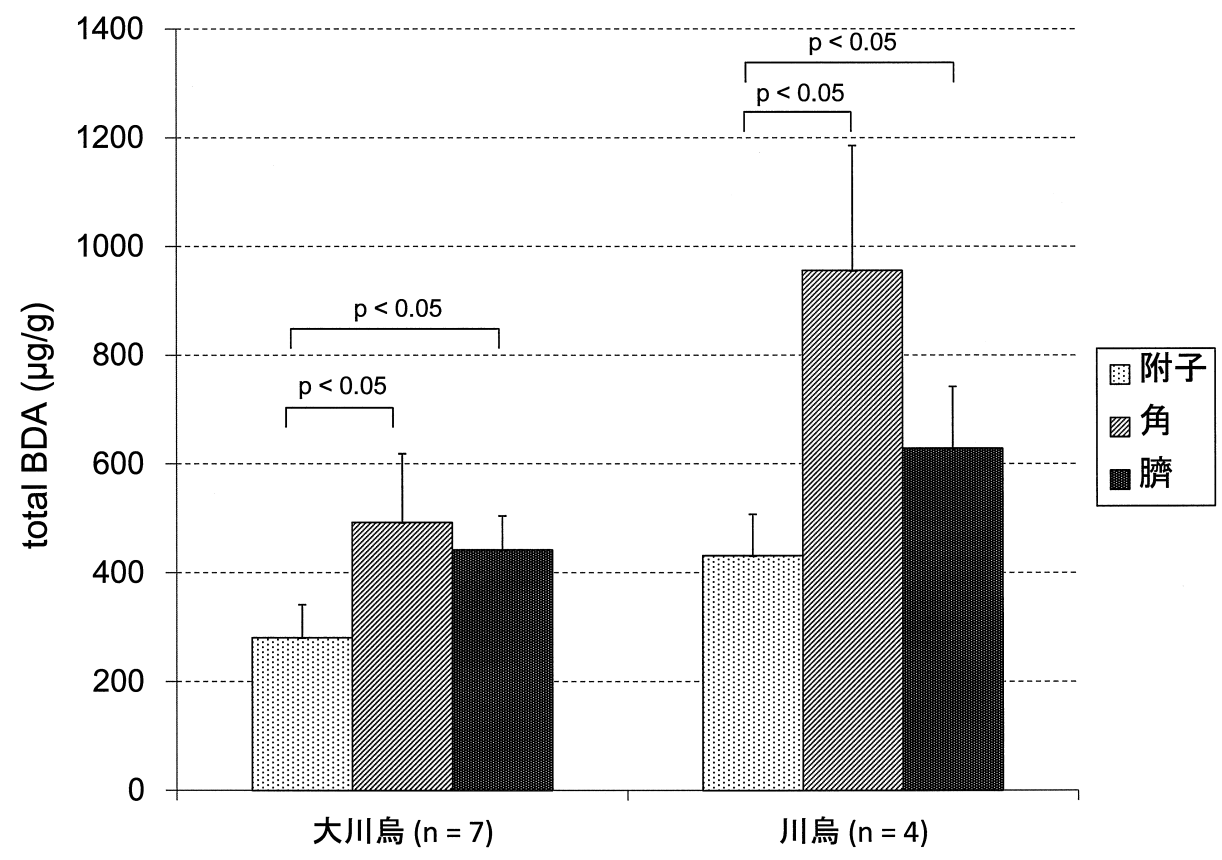

図 5 生薬各部位における BDA 含量

(ACO) $0.5 \mathrm{mg}$ ，メサコニチン (MES) $0.1 \mathrm{mg}$, ヒパコニチン (HYP) $0.15 \mathrm{mg}$, ジェサコニチン (JES) $0.05 \mathrm{mg}$ ]

2) HPLC 法による BDA 含量の定量

子根から細根基部の肥大部と根頭部を切り離し, それぞれを「附子」，「角」，「臍」とした。50号 (300 $\mu \mathrm{m} ）$ の篩に通るよう中末にして，デシケーターに て十分に乾燥したものを分析用試料とした。

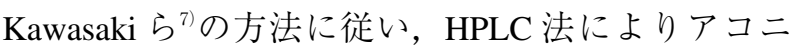
チン，メサコニチン，ヒパコニチン，ジェサコニチ ンの含量を測定した。

\section{3 ）実験結果}

両サンプルで附子の子根本体（附子）よりも, 細 根基部の肥大部（角）および根頭部（臍）の方が BDA 含量が有意に高いという結果が得られた（図 5 )。

\section{結論および考察}

1）附子の良品を本草学的に考証した結果，古来， 重さ一両を基準に附子の良否が鑑別されており，概 ね一両以上の大型で角（つの：細根基部肥大部）が ある附子を「八角」と呼び，尊ばれていたことが明 らかになった。一般に，生薬を科量する際の一両は 約 $12.5 \mathrm{~g}$ とされてきたことから, この值は乾燥重量 を示していたものと判断される。薬用部の子根は, 大型になるほど BDA 含量のバラツキが小さく低值 に安定するという報告 ${ }^{7}$ があることから，BDA 含量
が低い附子すなわち低毒性でかつ毒性が安定したも のを良質品としていたと考察した。

2 ）良質品附子の形状について古来，「節角が少 なく，底が平らで蹲坐したもの」とされてきた附子 とは，すなわち大型の原材料（子根）から細根基部 肥大部 (節・角) および根頭部（臍）を切り取り, 上下を逆さまにした形であることを明らかにした。 このことから，「八角」とは附子に加工する前の原 料の状態を指したもので，使用時は修治によって取 り除かれていたと考証した。

3 ）本研究により，根頭部（臍）および細根基部 肥大部（角）は子根本体に比べて BDA 含量が高い ことが明らかになった。したがって，臍と角を取り 除く修治法は BDA 含量を低くする意眓があったも のと考察され，このことからも低毒性の附子が良質 品とされていたと判断される。なお，現在市場には 本実験に供したような細根基部肥大部を残した商品 も出回っており，使用時には注意が必要である。

4 ）附子中の成分には higenamine や coryneineな ど BDA と異なる型のアルカロイドもあり，その薬 理活性が報告されている2)。一方，ブシのアルカロ イド以外の水溶性物質に体温上昇作用があるという 報告5)があり，また明治から昭和にかけて日本で使 用されていた勝山附子は無毒性であったことが知ら れている ${ }^{8}$ 。本研究で，附子の加工に際しては，原 料の選品においてもその修治法においても，毒性を 
低くする目的があったことが明らかになった。この ことから, 古来, 附子の毒性が大きな問題であった ことが推察され, 先人達が毒性 (BDA 含量) を減 少させることに苦心してきた背景が窥える。また， 有毒成分が薬効をも担っているなら使用量を調節す ることで対処できたはずで，あえて毒性を低くする 修治を行なってきたことは，薬効成分と有毒成分が 別であることを示唆しているとも考えられる。今後, さらなる活性成分の探索が必要であるが, 本研究に より，少なくとも古来の良質品附子は BDA 含量が 低值に安定したものであったことが明らかになった。

\section{引用文献}

1 ) 中国文化研究会編纂: 中国本草全書, 華夏出版社, 北 京, 1999 ； a）艾晟ら：経史証類大観本草, 10, pp. 289-

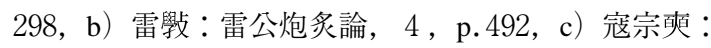
本草衍義, 16, p. 406, d) 楊天恵：彰明附子記， 6 , pp. 581-583, e) 汪昂: 本草備用, 100, pp.325-327, f）小野蘭山：本草綱目啓蒙，332，pp.462-464, g) 尚従善：本草元命苍，22, pp.235-237, h) 許兆禎： 薬準, 23, pp. 239-241, i) 許希周：薬性粗評, 56, pp. 47-49, j) 陳嘉謨 : 本草蒙鉒, 57, pp. 111-113, k) 皇甫嵩: 本草發明, $56, p p .471-472,1)$ 梅得元：新 鐟薬性会元, 76, pp. 425-426, m) 李時珍 : 本草綱目, 44, pp. 146-162, n）余應奎：太医院遺本草歌訣雷公 炮製，55, p. 352, o）葉文齢：新刊校正李東垣官板薬 性大全, 78, pp. 506-507,p）李中立: 本草原始, 62, pp. 126-127, q) 李中梓: 鑴補雷公炮製薬性解, 68, pp. 377-378, r) 李中梓: 医宗必読, 71, pp. 507-508, s）李中梓: 本草通玄, 95, pp. 122-123, t ) 張志聰： 本草崇原, 95, pp.466-469, u) 閔鐵：本草詳節， 92, pp.231-233, v) 尤乗: 薬品弁義, 96, p. 560, w) 張 璐：本経逢原, 101, pp. 195-199, x) 汪紱：医林纂要 探源, 103, pp. 431-432, y) 黄宮紼: 本草求真, 125, pp. 79-82, z) 鄭奮揚：増訂偽薬條弁, 147, pp. 525526, A）遠藤元理：本草弁義, 313, p. 510, B）稲生 若水: 炮多全書, 314, pp. 503-504, C) 岡本為竹： 広益本草大成, 317, pp. 307-319, D）貝原益軒：大
和本草, 319, pp. 232-234, E) 不明: 本草和解, 310, pp. 394-396, F) 井上玄通: 本草製譜, 321, pp. 170$173, \mathrm{G})$ 香月牛山：薬籠本草, $323, \mathrm{pp} .203-210, \mathrm{H}$ ) 香川修庵: 一本堂薬選, 324, pp. 64-66, I) 平住専 安: 本草售, 321, pp. 340-342, J) 松岡定庵: 千金方 薬注, 329, pp. 220-221, K) 加藤謙齊：増補片玉六 八本草, $320, \mathrm{pp} .481-485, \mathrm{~L})$ 吉益東洞: 薬徵, 327 , pp. 481-485, M) 内藤尚賢: 古方薬品考, 342, pp. 364-367, N）陶弘景：本草経集注，5, p. 164，O） 呉儀洛：本草従新, 109, pp.101-103, P) 下津元知： 図解本草，313，pp. 332-335，Q）王好古：湯液本草, 22 , pp. 100-101, R) 胡仕可：本草歌括, 83, p. 271, S）勝弘：神農本経会通，53,pp. 153-156, T) 鄭二 陽：仁寿堂薬鏡, 78, pp. 388-392, U）楊崇魁：本草 真詮, 63, p. 136, V) 繆希雍 : 炮多大法, 62, pp. 526527, W) 顧元交: 本草彙箋, 87, pp. 203-207, X) 葉桂: 本草経解要, 104, pp.305-306, Y) 王文潔： 新刻太乙仙製本草薬性大全, 58, pp. 70-72, Z) 林玉 友: 本草輯要, 113, pp. 290-292

2 ) 大泉康, ヒキノヒロシ：附子およびその成分の薬理. 附子の研究第二編, 三和生薬株式会社, pp. 117 155, 1981

3 ) 厚生労働省 : 第十六改正日本薬局方, pp. 1576-1577, 2010

4 ) 岡田浩明, 川口數美：トリカブトの新品種の育成, J. Nat. Med., 58(4), 145-149, 2004

5 ) Makino T., Kato K. and Mizukami H. : Processed Aconite Root Prevents Cold-Stress-Induced Hypothermia and Immuno-Suppression in Mice, Biol. Pharm. Bull., 32 (10), 1741-1748, 2009

6 ) 小泉袈乷勝: 歴史の中の単位, 総合科学出版, 東京, 1974

7 ) Kawasaki R., Motoya W., Atsumi T., Mouri C., Kakiuchi N. and Mikage M.: The relationship between growth of the aerial part and alkaloid content variation in cultivated Aconitum carmichaeli Debeaux, J. Nat. Med., 65(1), 111115, 2011

8 ) 難波恒雄: Aconitum 属植物の生薬学的研究 2 . 日本 産附子・烏頭類について (キンポウゲ科植物の生薬学 的研究第 4 報), 生薬学雑誌, 15(1), 197-238, 1961 